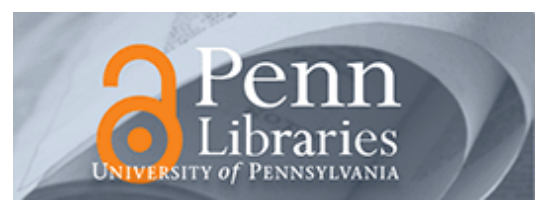

Manuscript Studies

\title{
In the Orbit of the Sphere: Sacrobosco's De Sphaera Mundi in UPenn MS Codex 1881
}

Aylin Malcolm

University of Pennsylvania, malcolma@sas.upenn.edu

Follow this and additional works at: https://repository.upenn.edu/mss_sims

Part of the Digital Humanities Commons, History of Science, Technology, and Medicine Commons, Medieval Studies Commons, and the Renaissance Studies Commons

\section{Recommended Citation}

Malcolm, Aylin () "In the Orbit of the Sphere: Sacrobosco's De Sphaera Mundi in UPenn MS Codex 1881," Manuscript Studies: Vol. 5 : Iss. 1 , Article 7.

Available at: https://repository.upenn.edu/mss_sims/vol5/iss1/7 


\title{
In the Orbit of the Sphere: Sacrobosco's De Sphaera Mundi in UPenn MS Codex
} 1881

\begin{abstract}
Johannes de Sacrobosco's De sphaera mundi was the most popular astronomical text in Europe from the late thirteenth century to the late seventeenth, and a core component of the university curriculum. This essay is the first published study of a remarkable copy of De sphaera in a manuscript recently acquired by the University of Pennsylvania (MS Codex 1881), which includes an unedited commentary on De sphaera and a variety of diagrams. I begin by addressing the textual relationships between this codex and other fifteenth-century copies of the main text and commentary, including both manuscripts and incunables. I then evaluate its diagrams, which would have assisted readers in visualizing and memorizing topics introduced in the main text, and which range from simple geometrical volvelles to a compendious climata diagram. To conclude, I consider what MS Codex 1881 might offer twenty-first-century audiences, including my initial work on digital editions of its diagrams. As a useful case study for both research and teaching, this manuscript will likely benefit several areas of inquiry in medieval and early modern studies, including the history of science and the history of education.
\end{abstract}

\section{Keywords}

Astronomy, Fifteenth Century, History of Science, Johannes de Sacrobosco, Robert Grosseteste, Diagrams, History of Education, Digital Editing, Early Print, Manuscript Studies 


\section{MANUSCRIPT STUDIES}

A Journal of the Schoenberg Institute for Manuscript Studies

VOLUME 5, NUMBER 1

(Spring 2020)

Manuscript Studies (ISSN 2381-5329) is published semiannually

by the University of Pennsylvania Press

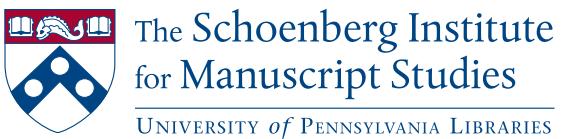




\section{MANUSCRIPT STUDIES}

VOLUME 5 , N U M B E R 1

(Spring 2020)

ISSN 2381-5329

Copyright (C) 2020 University of Pennsylvania Libraries

and University of Pennsylvania Press. All rights reserved.

Published by the University of Pennsylvania Press, 3905 Spruce Street, Philadelphia, PA 19104.

Printed in the U.S.A. on acid-free paper.

Manuscript Studies brings together scholarship from around the world and across disciplines related to the study of premodern manuscript books and documents, with a special emphasis on the role of digital technologies in advancing manuscript research. Articles for submission should be prepared according to the Chicago Manual of Style, $16^{\text {th }}$ edition, and follow the style guidelines found at http://mss.pennpress.org.

None of the contents of this journal may be reproduced without prior written consent of the University of Pennsylvania Press. Authorization to photocopy is granted by the University of Pennsylvania Press for libraries or other users registered with Copyright Clearance Center (CCC) Transaction Reporting Service, provided that all required fees are verified with CCC and paid directly to CCC, 222 Rosewood Drive, Danvers, MA 01923. This consent does not extend to other kinds of copying for general distribution, for advertising or promotional purposes, for creating new collective works, for database retrieval, or for resale.

\section{SUBSCRIPTION INFORMATION:}

Single issues: $\$ 30$

Print and online subscriptions: Individuals: \$40; Institutions: \$94; Full-time Students: \$30 International subscribers, please add $\$ 19$ per year for shipping.

Online-only subscriptions: Individuals: $\$ 32$; Institutions: $\$ 82$

Please direct all subscription orders, inquiries, requests for single issues, address changes, and other business communications to Penn Press Journals, 3905 Spruce Street, Philadelphia, PA 19104. Phone: 215-573-1295. Fax: 215-746-3636. Email: journals@pobox.upenn.edu. Prepayment is required. Orders may be charged to MasterCard, Visa, and American Express credit cards. Checks and money orders should be made payable to "University of Pennsylvania Press" and sent to the address printed directly above.

One-year subscriptions are valid January 1 through December 31. Subscriptions received after October 31 in any year become effective the following January 1 . Subscribers joining midyear receive immediately copies of all issues of Manuscript Studies already in print for that year.

Postmaster: send address changes to Penn Press Journals, 3905 Spruce Street, Philadelphia, PA 19104.

Visit Manuscript Studies on the web at mss.pennpress.org. 


\section{MANUSCRIPT STUDIES \\ A Journal of the Schoenberg Institute for Manuscript Studies}

VOL UME 5, N UMBER 1

Yemeni Manuscripts Online: Digitization in an Age

of War and Loss

NANCY UM

Opening the Text in the Floreffe Bible (London, BL Add. MS

17738): From Ways of Seeing to Ways of Touching

DOMINIC MARNeR

Litterae florissae in English Manuscripts in the Late Twelfth/

Early Thirteenth Century

Sara Charles

The Durham Latin Prose "Brut" to 1347 with a Continuation

to 1348: A Nationalistic Chronicle of England and Its

Manuscripts

Trevor Russell Smith

A Brief Introduction to Seventeenth-Century Military

Manuscripts and Military Literacy

Lucian Staiano-Daniels

\section{Annotations}

How Many Glyphs and How Many Scribes? Digital

Paleography and the Voynich Manuscript

Lisa Fagin Davis

In the Orbit of the Sphere: Sacrobosco's De sphaera mundi in UPenn MS Codex 1881 
Manuscript Studies, Vol. 5 [], Iss. 1, Art. 7

iv | Journal for Manuscript Studies

\section{Reviews}

Erik Kwakkel and Rodney Thompson, eds. The European Book in the Twelfth Century.

JoANnA Fronska

Paul M. Love, Jr. Ibadi Muslims of North Africa: Manuscripts, Mobilization, and the Making of a Written Tradition.

Amanda Propst

Jeffrey F. Hamburger, Robert Suckale, and Gude SuckaleRedlefsen, eds. Painting the Page in the Age of Print: Central European Manuscript Illumination of the Fifteenth Century.

Gregory Clark

Erik Kwakkel, ed. Vernacular Manuscript Culture, 1000-1500.

Hannah Morcos

Gaudenz Freuler. The McCarthy Collection, Volume I:

Italian and Byzantine Miniatures.

BRyAN C. KeEne 


\title{
In the Orbit of the Sphere: \\ Sacrobosco's De sphaera mundi in UPenn MS Codex 1881
}

\author{
Aylin Malcolm \\ University of Pennsylvania
}

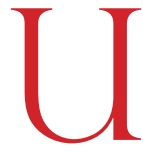

NIVERSITY STUDENTS TODAY ARE typically advised to obtain the latest editions of required texts, often at a markedly higher cost. Even when a textbook's basic content remains unchanged, instructors may favor a new edition for logistical reasons: previous versions may contain different exercises, or the page numbers may have shifted, making communal reading challenging. In contrast, few instructors at medieval universities could have depended on students possessing identical copies of common texts, even when scribal errors were minimal. Manuscript textbooks were highly customizable, and the formats and paratexts of surviving examples often speak to their owners' needs, ambitions, and social positions. For example, Johannes de Sacrobosco's De sphaera mundi (or Tractatus de sphaera) was the most common astronomical text in Europe from the late

\footnotetext{
This article presents research that I conducted as a graduate fellow at the Schoenberg Institute for Manuscript Studies. I am very grateful to the Schoenberg Institute for supporting my project, to Lynn Ransom and Nicholas Herman for their ongoing mentorship, and to Amey Hutchins for proofreading my transcriptions.
} 
thirteenth century to the late seventeenth. ${ }^{1}$ Composed around the year 1230 , this brief introduction to the Ptolemaic cosmos was soon in widespread use by teachers of the quadrivium, which all university students were expected to master before pursuing the higher faculties, such as law or theology. Yet manuscripts of De sphaera vary considerably with respect to their layouts, annotations, and illustrations. The characteristics of specific copies therefore grant insight into the uses of De sphaera in particular regions and periods, as well as the readers that it attracted. ${ }^{2}$ In what follows, I present the first focused study of a remarkable copy of De sphaera, and situate its textual and visual features in the context of fifteenth-century astronomical literature.

In 2017, the Kislak Center for Special Collections, Rare Books and Manuscripts at the University of Pennsylvania acquired the manuscript now known as MS Codex 1881 (hereafter 1881) from Conception Abbey, a Benedictine monastery in northwest Missouri. Bound in modern parchment, this codex consists of ninety-three paper leaves measuring $307 \times 205$ millimeters, and contains several of the most influential astronomical texts of premodern

1 For the standard edition and translation of De sphaera mundi, see Lynn Thorndike, The "Sphere" of Sacrobosco and Its Commentators (Chicago: University of Chicago Press, 1949). Extant manuscripts of De sphaera number in the hundreds; see Olaf Pedersen, "In Quest of Sacrobosco," Journal for the History of Astronomy 16, no. 3 (1985): 175-220 at 183. For an indication of its popularity as a printed text, see the database maintained by the Max Planck Institute for the History of Science, which includes 359 editions of De sphaera and related texts: Matteo Valleriani, dir., "The Sphere: Knowledge System Evolution and the Shared Scientific Identity of Europe," https://sphaera.mpiwg-berlin.mpg.de (accessed 20 December 2019). See also the list of 287 editions compiled by Roberto de Andrade Martins and hosted by the Grupo de História, Teoria e Ensino de Ciências: "Johannes de Sacrobosco: Editions of the Tractatus de Sphaera," http://www.ghtc.usp.br/server/Sacrobosco/Sacrobosco-ed.htm (accessed 20 December 2019).

2 De sphaera was translated into numerous languages, allowing it to reach individuals who were not studying at universities, including many women. See Kathleen M. Crowther and Peter Barker, "Training the Intelligent Eye: Understanding Illustrations in Early Modern Astronomy Texts," Isis 104 (2013): 429-70 at 431; Kathleen Crowther, Ashley Nicole McCray, Leila McNeill, Amy Rodgers, and Blair Stein, "The Book Everybody Read: Vernacular Translations of Sacrobosco's Sphere in the Sixteenth Century," Journal for the History of Astronomy 46, no. 1 (2015): 4-28. 
Europe, accompanied by intricate diagrams and six intact volvelles. ${ }^{3}$ Among these texts are the Theorica planetarum, a textbook describing epicyclic planetary motion (fols. $1 \mathrm{r}-14 \mathrm{v}) ;^{4}$ the Alfonsine tables, a popular tool for calculating eclipses and planetary positions (fols. $40 \mathrm{r}-61 \mathrm{v}$ ) $;^{5}$ and a glossed, annotated, and illustrated copy of Sacrobosco's De sphaera mundi (fols. 15r-36v), making 1881 the fourth De sphaera manuscript at the Kislak Center. ${ }^{6}$ Dated " 1481 " in a colophon at the end of De sphaera (fol. 36v), 1881 is written in a German Gothic cursive script, and the margins of the Alfonsine tables contain additional calculations for several European cities (Erfurt, Leipzig, Magdeburg, Mainz, Nuremberg, Paris, Prague, and Worms). One of these cities, Magdeburg, is transliterated into Hebrew near the end of the manuscript (fol. 95v), hinting at an origin in what is now northern Germany. $^{7}$

Collectively, the contents of 1881 serve as a complete introduction to late medieval astronomy in both its theoretical and technical aspects, and many of its texts are complementary. ${ }^{8}$ For instance, despite its clear explanations of the structure of the universe, the celestial sphere, the terrestrial climes, and the causes of eclipses, De sphaera contains little information on planetary motion. Many manuscripts and print editions therefore combined $D e$

3 Each volvelle consists of one (fols. 1v, 13v, 19v, 25v) or two (35r, 35v) paper or parchment disks attached to the page with thread. Fol. 20r contains traces of a volvelle that has been lost. 4 Incipit on fol. 2r of 1881: "[C]Irculus ecentricus dicitur vel egresse cuspidus vel egredientus centri ....” Often ascribed to either Gerard of Cremona (c. 1114-1187) or the thirteenthcentury translator Gerardo da Sabbioneta, this Theorica planetarum was one of several treatises by this name. For an English translation, see Olaf Pedersen, trans., "The Theory of the Planets," in A Source Book in Medieval Science, ed. Edward Grant (Cambridge, MA: Harvard University Press, 1974), 451-65.

5 For an edition and commentary, see José Chabás and Bernard R. Goldstein, The Alfonsine Tables of Toledo, Archimedes 8 (Dordrecht: Kluwer Academic, 2003).

6 Other copies are found in LJS 26 (Italy, ca. 1225-1275, in Latin), LJS 216 (France, ca. 1256-1270, in Latin), and LJS 494 (Italy, ca. 1425-1450, in Hebrew).

7 Fol. 95v also includes a Hebrew alphabet and a handful of other words in Hebrew with Latin transliterations, including the name "Jacob Affraiim."

8 Richard J. Oosterhoff describes this combination of Theorica planetarum, De sphaera, and Tabulae as "a complete set of astronomer's tools." See “A Book, a Pen, and the Sphere: Reading Sacrobosco in the Renaissance," History of Universities 28, no. 2 (2015): 1-54 at 4-5. 
sphaera with one of several Theorica planetarum texts describing the movements of the planets, with the text in 1881 being the most popular. ${ }^{9}$ Some of the texts in 1881 are also glossed or annotated; in particular, De sphaera mundi contains a complete commentary, written in a smaller size between sections of the main text, as well as interlinear glosses providing synonyms or definitions of difficult words. Perhaps most notable is the rich variety of diagrams in this manuscript, themselves often densely annotated. Figure 1 shows each of these components on the first page of the main text of $D e$ sphaera, which begins with a large initial " $\mathrm{T}$ " in the left column.

Students could therefore use this codex to gain a basic understanding of astronomical concepts and calculations without referring to additional texts or glosses. More advanced scholars could also use its paratext, particularly the De sphaera commentary, as a model for their own expositions, while its diagrams would have helped readers to visualize and memorize topics introduced in the main text. ${ }^{10}$ In particular, these diagrams would have encouraged students to develop what Kathleen M. Crowther and Peter Barker call the "intelligent eye," or the capacity to progress from a two-dimensional astronomical drawing to a dynamic mental vision of the universe. ${ }^{11}$ Taken as

9 Olaf Pedersen, "The Origins of the Theorica planetarum," Journal for the History of Astronomy 12, no. 2 (1981): 113-23; Olaf Pedersen, "The Theorica planetarum Literature of the Middle Ages," Classica et Mediaevalia 23 (1962): 225-32. On the early modern legacy of the Theorica planetarum, see James Steven Byrne, "The Mean Distances of the Sun and Commentaries on the Theorica planetarum," Journal for the History of Astronomy 42, no. 2 (2011): 205-21; Isabelle Pantin, "The First Phases of the Theorice planetarum Printed Tradition (1474-1535): The Evolution of a Genre Observed Through Its Images," Journal for the History of Astronomy 43, no. 1 (2012): 3-26.

10 Both mental and physical images could function as mnemonic devices in the medieval ars memoriae, as Mary Carruthers demonstrates in two important monographs: The Book of Memory: A Study of Memory in Medieval Culture (Cambridge: Cambridge University Press, 1990), with a discussion of mental images at 21-24, and The Craft of Thought: Meditation, Rhetoric, and the Making of Images, 400-1200, Cambridge Studies in Medieval Literature 34 (Cambridge: Cambridge University Press, 1998), esp. 116-70. On the relationships between scientific texts and diagrams, see also J. D. North, "Diagram and Thought in Medieval Science," in Villard's Legacy: Studies in Medieval Technology, Science, and Art in Memory of Jean Gimpel, ed. Marie-Thérèse Zenner (Aldershot: Ashgate, 2004), 265-88.

11 Crowther and Barker, "Intelligent Eye," 430, 469-70. The authors focus on print editions of De sphaera and the Theorica planetarum, demonstrating the need for similar work on manuscripts. 
Malcolm: Sacrobosco's De Sphaera Mundi in UPenn MS Codex 1881

Malcolm, Orbit of the Sphere | 185

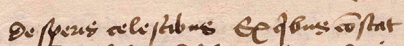

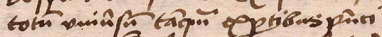

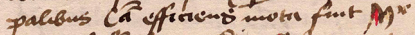

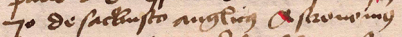

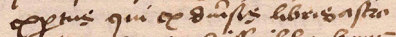

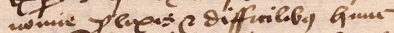

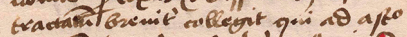

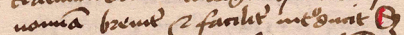

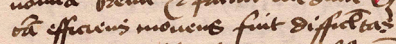

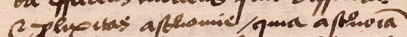

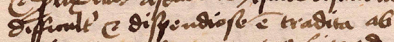

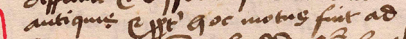

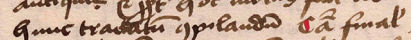

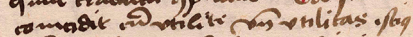

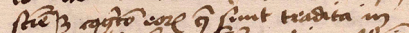

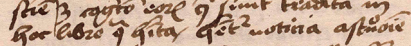

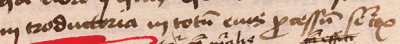

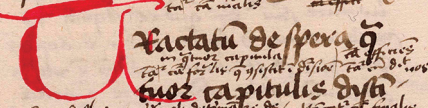

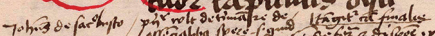
youning 3 ind amo fitspera onofotcucs rentep Cundaris perce sucs pola mit auct fut csperce eque fit forma morió T) pernte de are etulis Geq" Cus ber perve malos romponet?

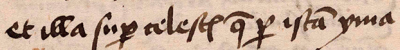

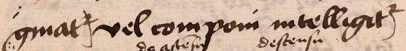

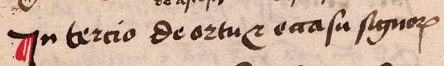

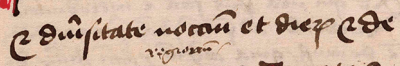
ancipone tematu $>$ in $\&$ to armas 2 motibeng Pronctaze

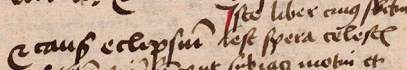

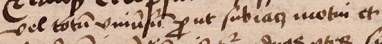

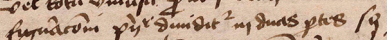

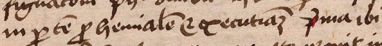

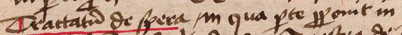

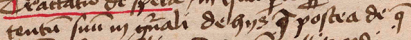

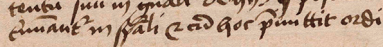

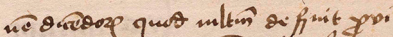

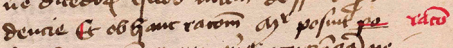

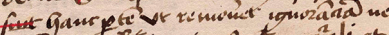

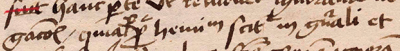

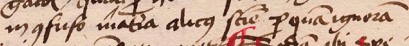

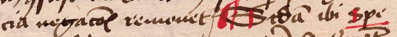

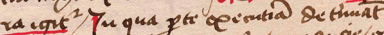

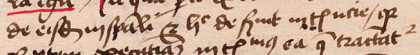

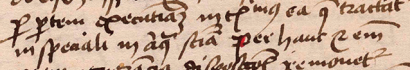

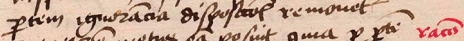

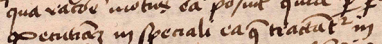

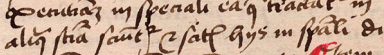

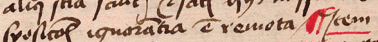

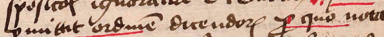

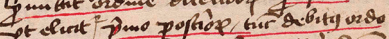
o poricose

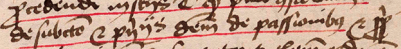

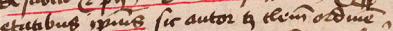

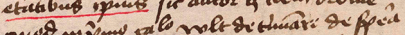

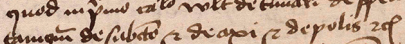

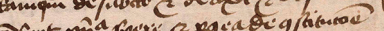

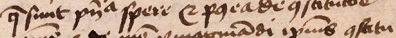

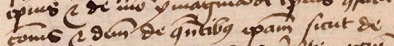

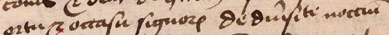

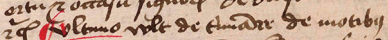

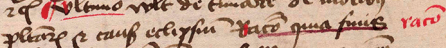

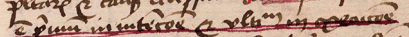

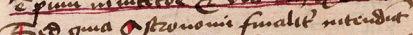

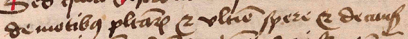

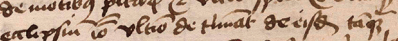

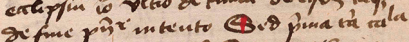

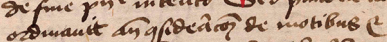
culipplows petase evidazat iff pro

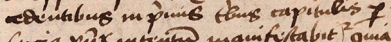

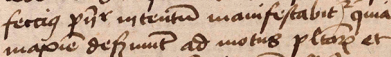

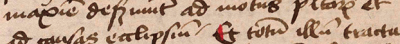

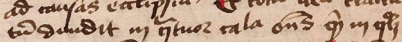

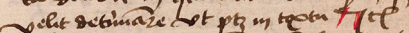

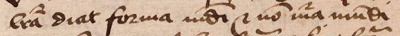
quid ina gonofot ${ }^{2} y$ term an finc for

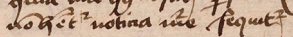

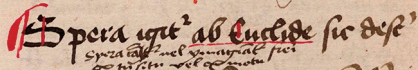

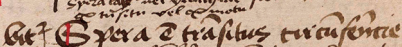

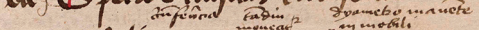

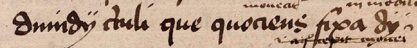

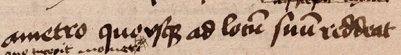

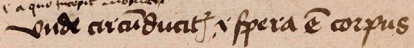

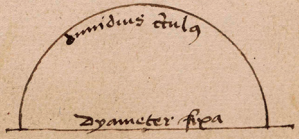

FIGURE 1. The opening of Johannes de Sacrobosco's De sphaera mundi, with main text, commentary, interlinear glosses, and a small marginal diagram. University of Pennsylvania, Kislak Center for Special Collections, Rare Books and Manuscripts, MS Codex 1881, fol. 15v. 
a whole, 1881 thus provides a snapshot of education in the late Middle Ages, as a manuscript that is broadly typical of its genre, but also-as the following analyses of the De sphaera section will show-exceptional in some of its textual and visual aspects.

\section{Texts and Technologies: Annotating "De sphaera mundi"}

Like all authoritative texts used in medieval universities, De sphaera mundi would generally have been taught alongside at least one commentary, often composed by the instructor. ${ }^{12}$ The resulting profusion of De sphaera commentaries remains an under-researched subject, albeit one of significant importance for both the history of science and the history of education; as Richard J. Oosterhoff observes, studying the uses of "typical" textbooks can clarify the context from which the well-known works of Copernicus and Galileo emerged. ${ }^{13}$ The earliest De sphaera commentaries include one ascribed to Michael Scot (early thirteenth century) that introduces fiftythree questions on Aristotelian natural philosophy, and the commentary by Robertus Anglicus (ca. 1271) that discusses the possibility of a world soul and cites the testimony of a spirit as proof of the equatorial region's habitability. ${ }^{14}$ Perhaps most noteworthy is Cecco d'Ascoli's commentary (ca. 1322-24), with its allusions to necromantic texts and strategies for summoning demons. This commentary led to Cecco's condemnation by the Inquisition in 1324, after which he was banned from teaching astrology. ${ }^{15} \mathrm{By}$ the time that 1881 was copied in the late fifteenth century, commentaries on De sphaera had become an important medium through which astronomy

12 Byrne, "Mean Distances of the Sun," 206.

13 Oosterhoff, "A Book, a Pen, and the Sphere," 2.

14 Lynn Thorndike's "Sphere" of Sacrobosco includes editions and analyses of the commentaries by Michael Scot, Robertus Anglicus, and Cecco d'Ascoli, as well as selections from anonymous commentaries.

15 The Inquisition sentenced Cecco to be burned at the stake with all copies of his published works in 1327, but many manuscripts of his texts survive. On his De sphaera commentary, see Thorndike, "Sphere" of Sacrobosco, 52-55. 
developed and expanded, as rising academic stars sought to build their reputations by criticizing and improving upon this text. ${ }^{16}$

The commentary in 1881 is anonymous and unedited, but not unique. Thus far, I have located similar texts in three other manuscripts. All three date from the fifteenth century, and all contain free-standing commentaries, in contrast to the interwoven main text and commentary of 1881 .

- Freiburg, Universitätsbibliothek Freiburg i. Br. / Historische Sammlungen 57, fols. 16r-31r. Dated "1409” on fol. 120v. Also contains an incomplete copy of De sphaera (fols. 1r-9r) and a copy of Sacrobosco's Algorismus (fols. 105r-112r). ${ }^{17}$

- Vatican City, Vatican Apostolic Library, Vat. lat. 3097, fols. 82r-102r. ${ }^{18}$

- Vienna, Österreichische Nationalbibliothek, Codex Vindobonensis 5145, fols. 72r-94v. Also contains a second commentary on Sacrobosco's De sphaera (fols. 12r-28r).

In 1881 , this commentary begins on folio $15 \mathrm{r}$, before the opening of the main text. Of the other three copies, only the Vienna manuscript includes this prefatory section:

Quia presens scientia

est introductoria ad

Astronomiam videlicet

per totum eius processum

16 For a summary of commentaries on De sphaera and their role in disseminating new astronomical theories, see James M. Lattis, Between Copernicus and Galileo: Christoph Clavius and the Collapse of Ptolemaic Cosmology (Chicago: University of Chicago Press, 1994), 41-45. On vernacular print commentaries, see also Crowther et al., "The Book Everybody Read," 4-28. A relevant collection edited by Matteo Valleriani, "De sphaera" of Jobannes de Sacrobosco in the Early Modern Period: The Authors of the Commentaries, is forthcoming from Springer in 2020.

17 A digital facsimile of this manuscript is available on the Digital Collections Freiburg website: http://dl.ub.uni-freiburg.de/diglit/hs57/0030 (accessed 20 December 2019).

18 A digital facsimile is available on the DigiVatLib website: https://digi.vatlib.it/view/MSS _Vat.lat.3097 (accessed 20 December 2019). 
Ideo primo videndum
est in generali de A-
stronomia Quid sit \& de eius diuisione. . . ${ }^{19}$

The Freiburg (fig. 2) and Vatican manuscripts open with variants of a passage occurring after the beginning of the main text in 1881 (fol. 15v): ${ }^{20}$

Iste liber cuius subiectum

est spera celestis

vel totum vniuersu $m^{21}$ prout subiacet motui et figuracioni principaliter diuiditur in duas partes scilicet in partem prohemiale $m \&$ executivam ${ }^{22}$ prima ibi Tractatu $m$ de spera / in qua parte proponit in tentum suum in generali de hiis quae postea de quae terminantur in speciali \& cum hoc premittit ordi nem dicendorum quod multum definit providencie Et ob hanc racionem Magister posuit po suit hanc partem vt remoueret ignoranciam negacionis / quia \per/ prohemium scitur in generali et in confuso materia alicuius scientie per quam ignoran cia negacionis remouetur....

19 This is a semi-diplomatic transcription of the text in 1881. All transcriptions in this essay use the following conventions: abbreviations are expanded with supplied letters italicized and superscript letters lowered. Rubricated letters in the manuscript are in bold. A forward slash indicates a virgule in the manuscript, and an ampersand ( $\&$ ) indicates an abbreviated "et." 20 The Freiburg manuscript contains the same text with minor variations. The Vatican text diverges after a few initial phrases, and its relationship to 1881 may be more distant.

21 The incipit "Iste liber cuius subiectum est totum universum" appears in Lynn Thorndike and Pearl Kibre, A Catalogue of Incipits of Mediaeval Scientific Writings in Latin (Cambridge, MA: The Medieval Academy of America, 1937), 788(1). Thorndike and Kibre link this incipit to the Vatican and Vienna manuscripts; the latter is incorrectly listed as Cod. 5154, fols. 12r-28r, although the other Sacrobosco commentary in the Vienna manuscript is correctly indexed under 498(3), "Elye est civitas illa ubi presides philosophi fuerunt."

22 The text in the Vatican manuscript diverges from 1881 at this point. 
Malcolm: Sacrobosco's De Sphaera Mundi in UPenn MS Codex 1881

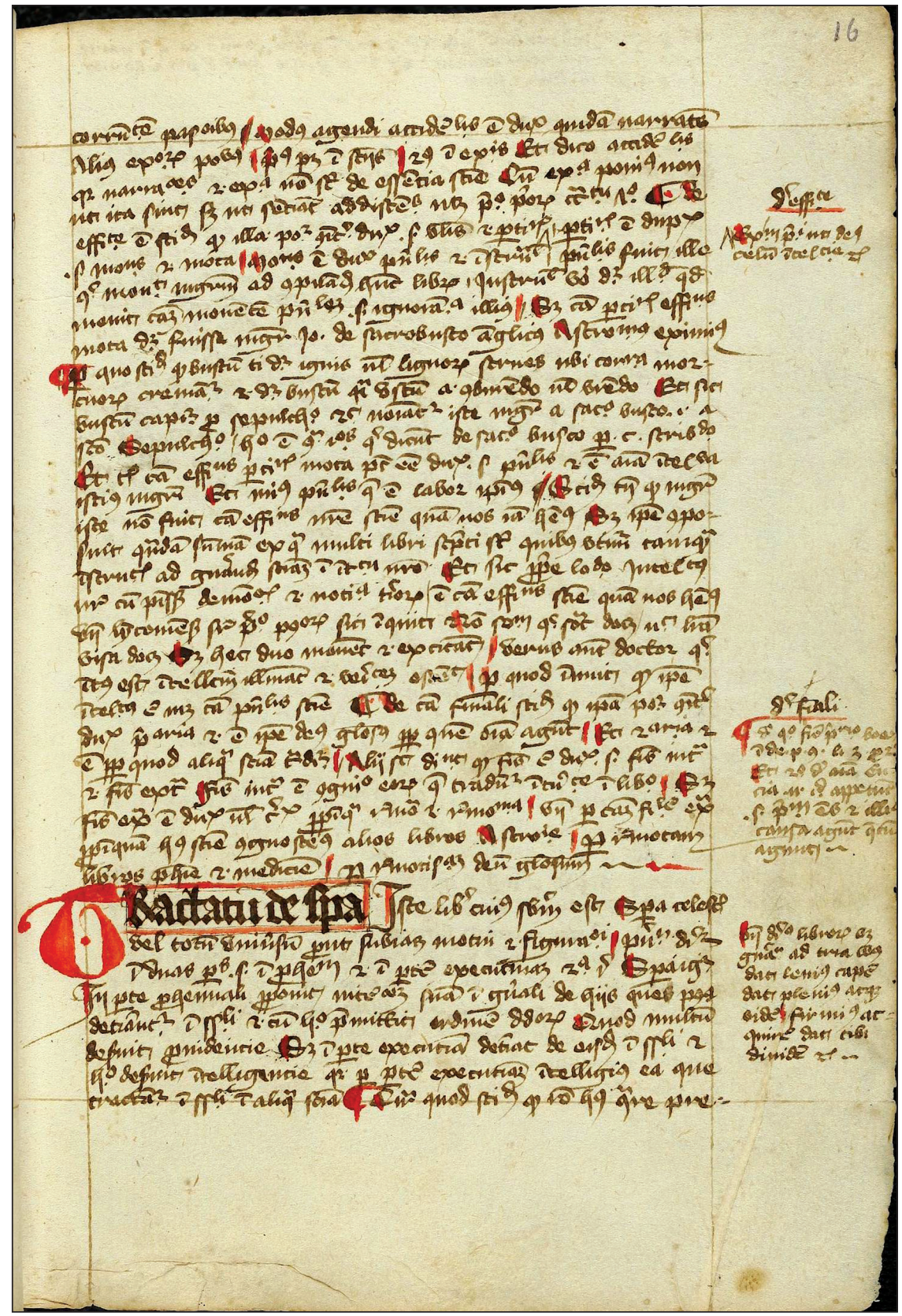

FIGURE 2. Beginning of the commentary on De sphaera mundi. Universitätsbibliothek Freiburg i. Br. / Historische Sammlungen 57, fol. 16r. 
Further research on this commentary stands to enhance our understanding of the ideas in circulation at the end of the medieval period, when the first print editions of De sphaera were emerging from Italy and Nicolaus Copernicus (1473-1543) was a young child.

If the De sphaera commentary tradition was continually developing, 1881 also demonstrates that De sphaera itself was not a stable object. One intriguing case of textual fluidity is a passage that has been added at the bottom of folio $28 \mathrm{r}$ and marked for insertion into Chapter 3 of the main text, in a discussion of the different modes of rising and setting of the signs. ${ }^{23}$ This passage does not occur in any of the thirteen manuscripts on which Thorndike bases his edition, and of the fifteen other Latin De sphaera manuscripts that I have consulted, it appears in only two, both copied in Italy: UPenn LJS 26 and Oxford, Bodleian Library, MS Digby 215. ${ }^{24}$ Yet it is remarkably similar to a passage typically appearing in Chapter 3 of Robert Grosseteste's De sphaera, an early thirteenth-century introduction to astronomy with many similarities to Sacrobosco's text. ${ }^{25}$ To illustrate this resemblance, I have compared the following transcription of the addition in 1881 with both LJS 26 (designated as "26" in notes) and the copy of Grosseteste's De sphaera in London, British Library, Harley MS 4350, fols. 10v-11r (“4350” in notes).

23 For an edition and translation of the main text, see Thorndike, "Sphere" of Sacrobosco, 97-98 and 130-31.

24 In addition to these two manuscripts, I have consulted three at Yale University (Beinecke MS 335, Beinecke MS 797, Yale Medical Library MS 22), five at the Bodleian Library (MS Additional A. 2, MS Ashmole 1285, MS Bodley 491, MS Canon Misc. 561, MS Digby 93), four at the British Library (Additional MS 31046, Arundel MS 268, Harley MS 531, Royal MS 12 C XVII), and UPenn LJS 216.

25 Ludwig Baur noted that this passage occurs in manuscripts of both authors' texts; see Die Philosophischen Werke des Robert Grosseteste, Bischofs von Lincoln (Münster: Aschendorffsche Verlagsbuchhandlung, 1912), 64*. For general comparisons of the content and phrasing of these two texts, see Matthew F. Dowd, "Astronomy and Compotus at Oxford University in the Early Thirteenth Century: The Works of Robert Grosseteste" (PhD diss., University of Notre Dame, 2003), 195-98, and Thorndike, "Sphere" of Sacrobosco, 10-14. For an edition of Grosseteste's De sphaera, see Cecilia Panti, ed., Moti, virtù e motori celesti nella cosmologia di Roberto Grossatesta (Florence: SISMEL: Edizioni del Galluzo, 2001). 
Malcolm: Sacrobosco's De Sphaera Mundi in UPenn MS Codex 1881

Malcolm, Orbit of the Sphere | 191

Sciendu $m$ est ${ }^{26}$ quod tam inspera recta quam obliqua / ascendit equinoctialis circulus $s^{27}$ / semper vniformiter scilicet in temporibus equalibus / equales arcus ${ }^{28}$ ascendunt / Motus enim celi vniformis est / et angulus quem facit $^{29}$ equinoctialis cum orizonte obliquo ${ }^{30}$ non diuersificatur in aliquibus horis ${ }^{31} /$ Partes vero zodiaci ${ }^{32}$ non de necessitate habent ${ }^{33}$ equales ascensiones in vtraque spera ${ }^{34} /$ Quia quanto aliqua pars ${ }^{35}$ rectius oritur / tanto plus temporis ${ }^{36}$ ponitur ${ }^{37}$ in suo ortu / huius $s^{38}$ signum est / quia sex ${ }^{39}$ signa oriuntur in longa vel breui die artificiali similiter $\&$ in nocte ${ }^{40}$

At present, it is difficult to determine whether this passage is original to Sacrobosco, to Grosseteste, or to another writer entirely. ${ }^{41}$ What is clear is that it was eventually incorporated into many print editions of De sphaera. Although it is absent from the earliest edition (Ferrara: Andreas Belfortis, 1472; ISTC no. ij00399600), it appears in all five of the Venetian editions

26 est] 26: tamen, 4350: igitur.

27 circulus] 26: arculus.

28 arcus] 4350: partes.

29 facit] 26: tangit.

30 obliquo] 26, 4350: aliquo.

31 horis] 4350 adds Arcus itaque de equinoctiali circulo qui ascendit cum aliqua parte zodiaci dicitur ascensio eiusdem partis.

32 zodiaci] 26 adds equales.

33 habent] $26 \mathrm{om}$.

34 in vtraque spera] $4350 \mathrm{om}$.

35 pars] 4350 adds zodiaci.

36 plus temporis] 26 om., 4350: maius tempus.

37 ponitur] 26, 4350: ponit.

38 huius] 26 adds autem.

39 sex] 26 adds quia.

40 huius signum est . . . similiter \& in nocte] $4350 \mathrm{om}$.

41 Scholars have yet to reach a consensus about which of the two De sphaera texts was composed first. Dowd, “Astronomy and Compotus," 197-98. 


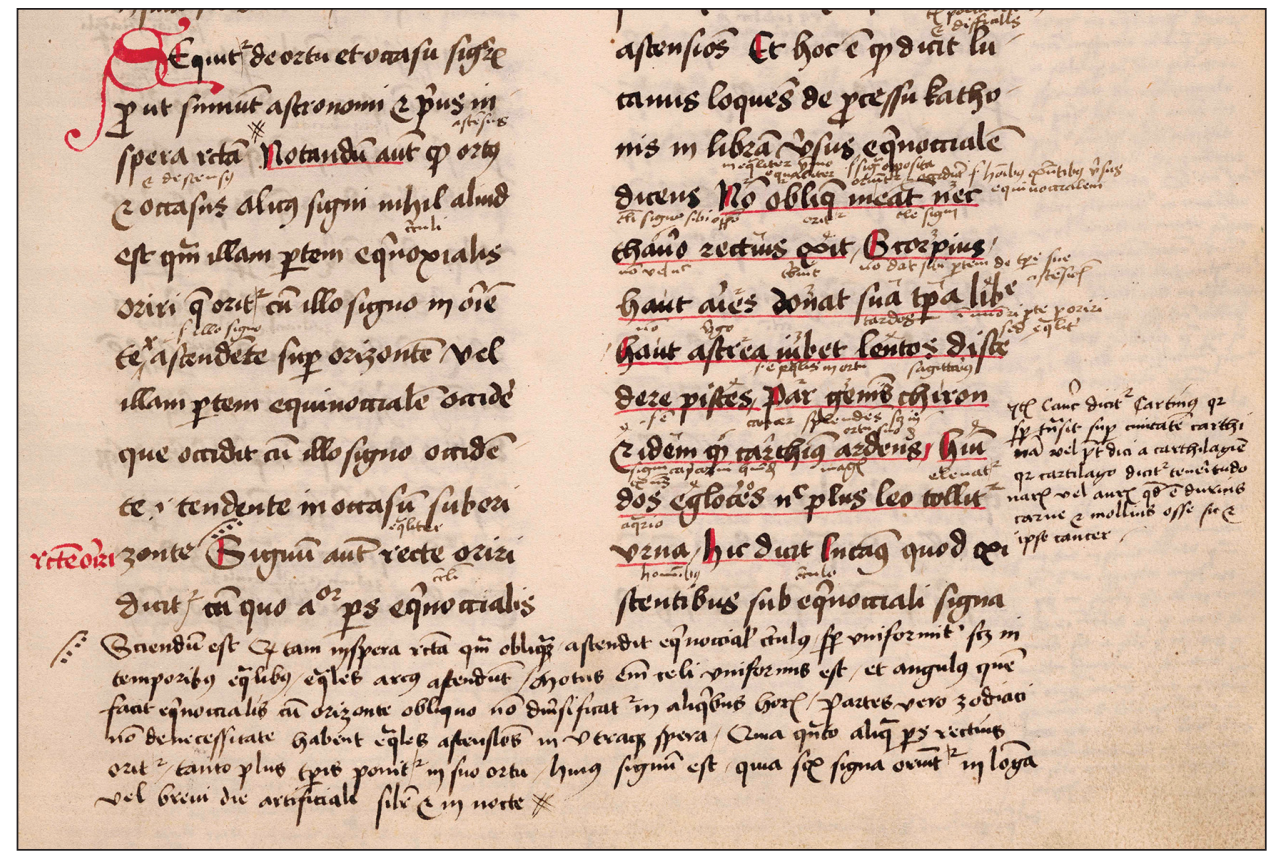

FIGURE 3. Addition to the third chapter of De sphaera mundi. University of Pennsylvania, Kislak Center for Special Collections, Rare Books and Manuscripts, MS Codex 1881, fol. 28r.

from the first decade of De sphaera's print history, added to the main text before "Notandum autem quod ortus et occasus ..." (fig. 4). ${ }^{42}$ We can therefore speculate that 1881 was copied from a version of De sphaera lacking this passage and updated using another version-which may well have been a print edition.

42 These Venetian editions were published in 1472 (printed by Florentius de Argentina; ISTC no. ij00400000), ca. 1476 (Filippo di Pietro; ISTC no. ij00401000), 1478 (Franz Renner; ISTC no. ij00402000, ca. 1478 (Adam de Rottweil; ISTC no. ij00403000), and 1482 (Erhard Ratdolt; ISTC no. ij00405000). Like the 1472 Ferrara edition, the editions printed by Florentius de Argentina (i.e., Strasbourg) and Franz Renner include the Theorica planetarum attributed to Gerard of Cremona, which Ratdolt's edition replaces with Georg von Peurbach's Theoricae novae planetarum. 
2Jü Lucanus fic inquit. Iunc nox tbeffalicas òrgebat parua \{s। gittas, Eliacus oztus:fiuc folaris:eft quando fignui vel ftella vide ri poteft per elongationé folis ab illo:qó paius videri lnó porerat folis ppinquitatc. Exemplī buius ponit Duidius in libzo oe fa/ Ptes fic. Jam leitis obliqua fubfedit aquarius vrna. Et 23 irgilt' in geozgicis. Snoliaqg ardentis oefcendit ftella cozonę. Quę iuxts f́ozpioné exiftens nó videbar: oum fol erat i f cospione. Decafus cliacus é:quädo fol ad fignũ accedit: $z$ illud fus paęentia $z$ lumi' nofitate videri nó pmittit. buius exemplü eft in verfu peentuilo. fej. Iaurus z aducrfo cedens canis occidit aftro.

\section{a De ortu z occafí figno/}

rum lecundũ aftrologos.

CSequit oe ostu z occafu figno\% put fumut aftronomi: $z$ pxius

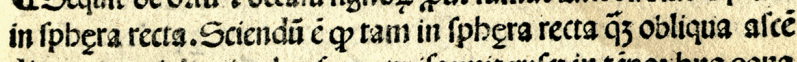
dit ęuunoctialis circulus femtg vriformiter: iss in tépoz bus equa libus equales arcus afcendunt. Ji jotus eni celi vniformis e e $\tau$ an gulus qué facit ęquịnoctialis cỉ bosijontc obliquo nó oiucrifica tur in aliquibus bosis. Partes vero jodiaci no oe neceffitate ba' bent ęquales afcéfiones in vtraq; fpbęra:q? quăto aliqua jodiaci pars rectius ozitur:tanto plus téposis ponit i fuo oztu. buius is/ gnum eft: qz fex figna osiunt in longa vel breui oie srtificiali. fimí liter $r$ in nocte. ONotandä igit $Q$ oztus vl occafus alicuius figni nibil aliud eft ä̉ tllă pré equinoctialis oziri que ozitur cum illo fî. gno oziente:vel afcédente fupza bosizonté: vcl illam partem equi! noctialis occidere quę occidit cả altero ligno occidentc. id é tandé te ad occafum fub bo:ijonte. Signum aute ii recte osiri oicitur cie quo maios pars equiroctialis ositur:obliquę vero cú quo minoz Similit ctiam intelligendi é oc occafu. CEt eft fciendī q i fpbę, ra recra quattuoz 3 odiaci incboate quattuoz pirctis:0uob? fcj foll

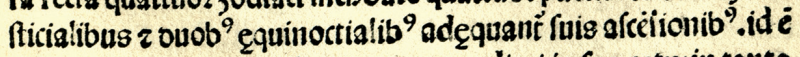
quantum tempozis confumit quarts jodiaci in fro ostu:in tanto

\section{b 2}

\footnotetext{
FIGURE 4. A section from the third chapter of De sphaera mundi in an early Venetian edition, including the passage added on fol. 28r of 1881. Johannes de Sacrobosco, De sphaera mundi (Venice: Erhard Ratdolt, 1482), B2r. Bryn Mawr College Libraries, Special Collections Department.
} 


\section{Compendious and Interactive Diagrams}

Diagrams were an integral component of medieval astronomical pedagogy, assisting students in developing mental images of the universe. ${ }^{43}$ Since it was impossible to observe the entire cosmos in motion, students were trained to construct images that they could visualize and—crucially-manipulate in the mind..$^{44}$ Basic textbooks often instructed readers to imagine rotating or otherwise moving the diagrams provided, and this skill was essential for more advanced astronomy; indeed, Crowther and Barker show that both Copernicus and Galileo presumed that their readers could create and manipulate mental images. ${ }^{45}$ However, the diagrams in De sphaera manuscripts remain under-studied, with most scholars having focused on print editions of this text. ${ }^{46}$ Even the number of illustrated De sphaera manuscripts is uncertain; only seven of the manuscripts used in Thorndike's edition contain diagrams, but their consistency suggests that, as Isabelle Pantin states, "a kind of iconographical tradition ... had been established as early as the second half of the thirteenth century." ${ }^{47}$

43 For an overview of late medieval astronomical diagrams, see Bruce Eastwood and Gerd Graßhoff, "Planetary Diagrams-Descriptions, Models, Theories: From Carolingian Deployments to Copernican Debates," in The Power of Images in Early Modern Science, ed. Wolfgang Lefèvre, Jürgen Renn, and Urs Schoepflin (Basel: Birkhäuser, 2003), 197-226 at 212-17.

44 Crowther and Barker, "Intelligent Eye," 436-38, 470. As Mary Carruthers observes, this skill was fundamental to the medieval curriculum; indeed, "almost every medieval diagram implies some degree of mental manipulation on the part of the student using it." See "Moving Images in the Mind's Eye," in The Mind's Eye: Art and Theological Argument in the Middle Ages, ed. Jeffrey Hamburger and Anne-Marie Bouché (Princeton: Princeton University Press, 2006), 287-305 at 294.

45 Crowther and Barker, "Intelligent Eye," 448-51.

46 See, for example, Owen Gingerich, "Sacrobosco Illustrated," in Between Demonstration and Imagination: Essays in the History of Science and Philosophy Presented to John D. North, ed. Lodi Nauta and Arjo Vanderjagt (Leiden: Brill, 1999), 211-24. Franz Renner's 1478 edition was the first to include diagrams, followed by the editions of Erhard Ratdolt (1482, ISTC no. ij00405000; 1485, ISTC no. ij00406000) and Johannes Santritter (1488, ISTC no. ij00407000).

47 Pantin, "First Phases," 3, 22 n. 1; Thorndike, "Sphere" of Sacrobosco. 
Yet whether one compares this codex with other manuscripts or with print editions, the number of images in 1881 is unusually high, and many of these images contain unusually large amounts of text. Nearly every page of De sphaera includes one or more diagrams, ranging from marginal sketches to detailed figures occupying half a page. Some concepts are associated with multiple images; thus in addition to the large diagram of the celestial spheres on folio $17 \mathrm{r}$ (fig. 5) - a typical feature of astronomical textbooks in general and of De sphaera in particular-folio $18 \mathrm{v}$ features a

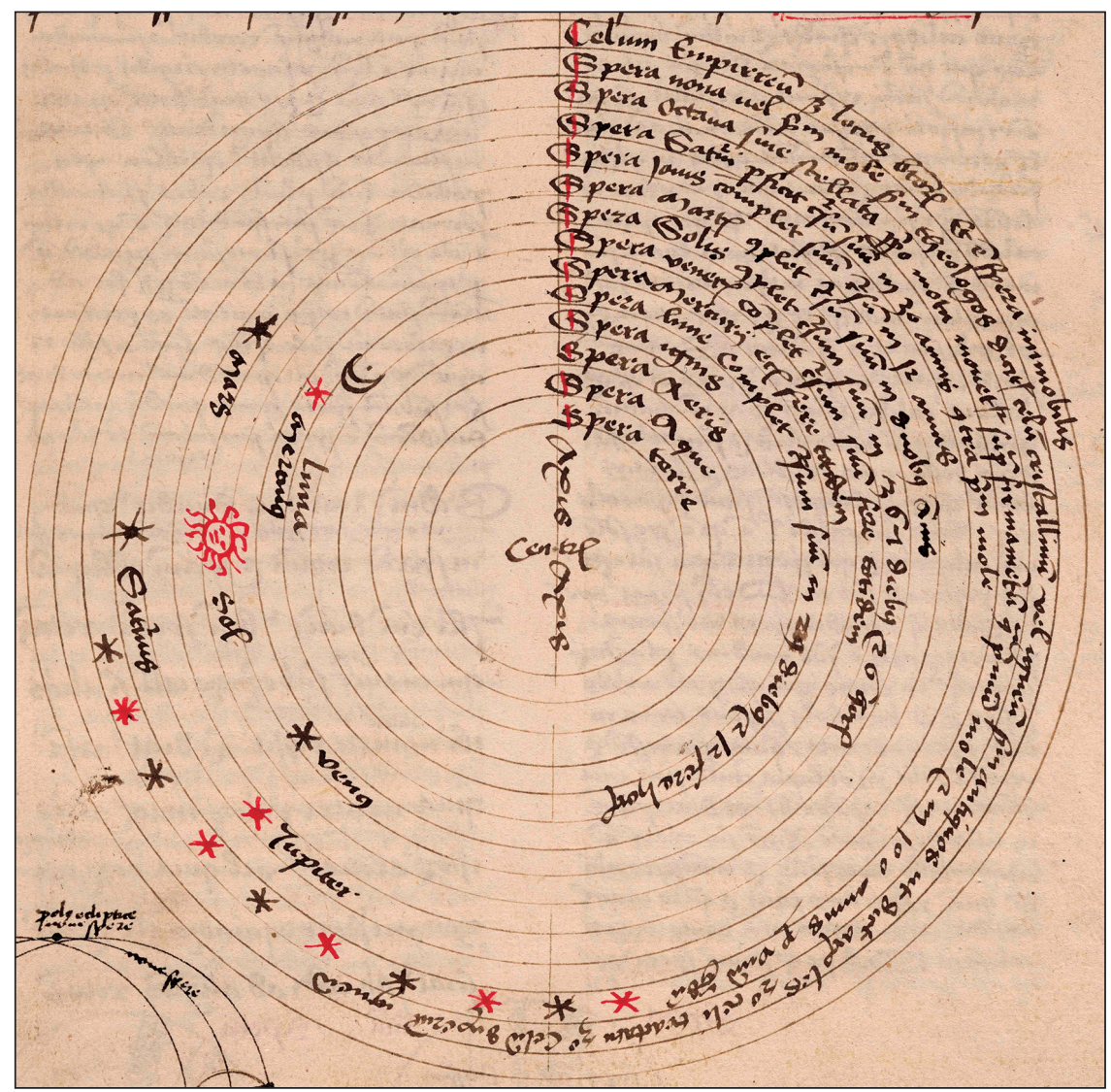

FIGURE 5. Diagram of the elemental and celestial spheres. University of Pennsylvania, Kislak Center for Special Collections, Rare Books and Manuscripts, MS Codex 1881, fol. 17r. 


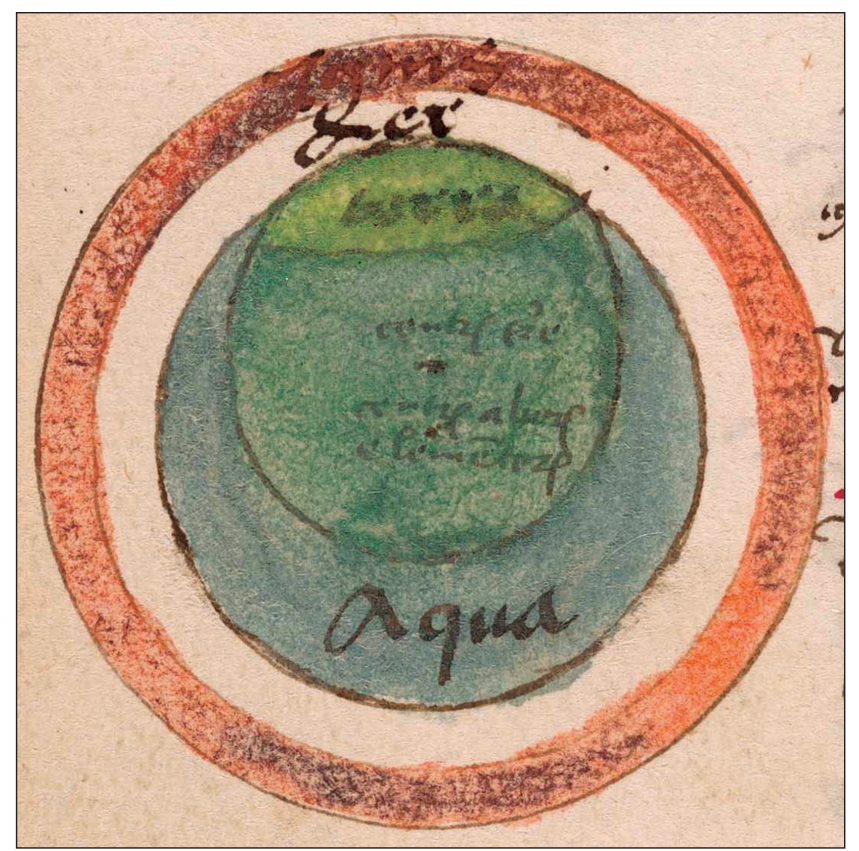

FIGURE 6. Diagram of the elemental spheres. University of Pennsylvania, Kislak Center for Special Collections, Rare Books and Manuscripts, MS Codex 1881, fol. 18v.

diagram of the elemental spheres in the left margin (fig. 6)..$^{48}$ The darker ink of many marginal drawings suggests that they were added later, possibly by a student attempting to commit an exemplar to memory. ${ }^{49}$

This copy of De sphaera also includes four of the six intact volvelles in 1881 (fols. 19v, 25v, 35r, and 35v). Beyond their function as attractive decorations, these model how a reader might mentally rotate static images presented elsewhere in the text. For instance, a simple triangular volvelle on folio $19 \mathrm{v}$, occurring next to a similar static image, illustrates the necessity for a spherical universe: by rotating this diagram, the viewer perceives that

48 On the uses of this "cosmic section" diagram in De sphaera, see Crowther and Barker, "Intelligent Eye," 453-55.

49 On this practice of copying diagrams to assist with memorization, see Oosterhoff, "A Book, a Pen, and the Sphere," 21-36. 


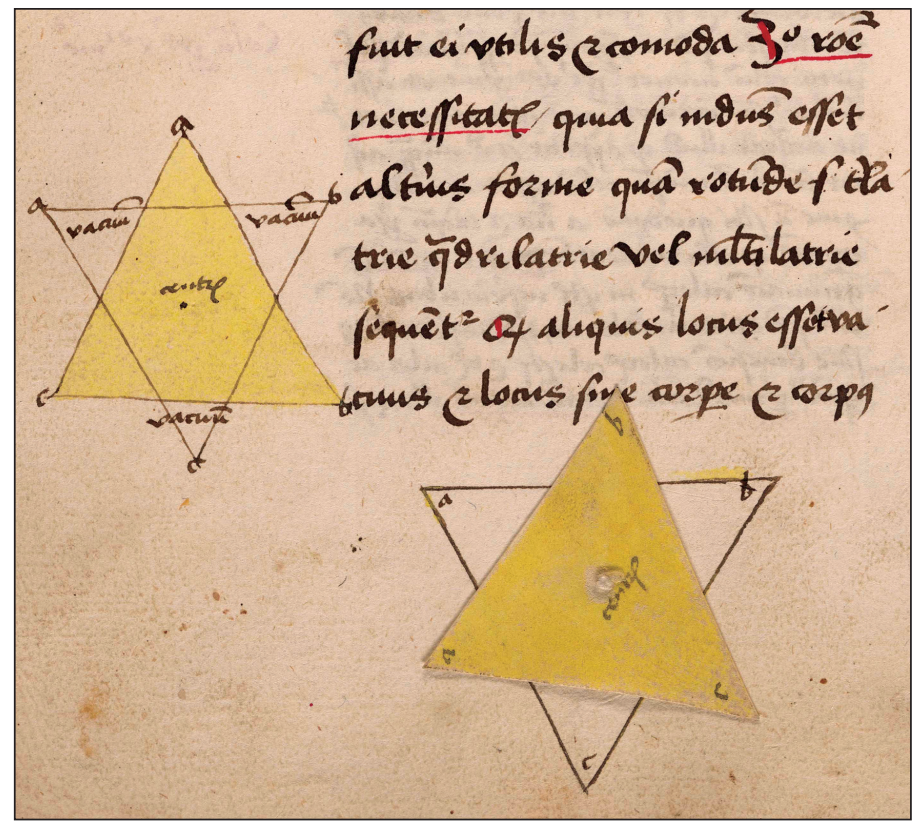

FIGURE 7. Triangular volvelle complementing a passage on the shape of the universe. University of Pennsylvania, Kislak Center for Special Collections, Rare Books and Manuscripts, MS Codex 1881, fol. 19v.

a triangular universe would create empty spaces as it rotated, identified as "vacuum" in the static image (fig. 7). Although these diagrams may seem basic, they prompt readers to develop the movable mental images required for more complex astronomy: as the volvelle rotates on the page, so readers must learn to rotate the nearby static image in their minds. The volvelles found later in De sphaera are more sophisticated, such as the diagram on $35 \mathrm{v}$, which uses an asymmetrical upper disk to depict the conditions under which an eclipse will occur, including the positions of the earth, sun, and moon (fig. 8). ${ }^{50}$

50 The phrases “caput draconis" and "cauda draconis" (head and tail of the dragon) on this diagram denote the intersections of the lunar deferent (a large circle around which the center of the moon's epicycle moves around the earth) and what Sacrobosco calls the lunar equant (a circle concentric with the earth in the plane of the ecliptic). A lunar eclipse would occur only 


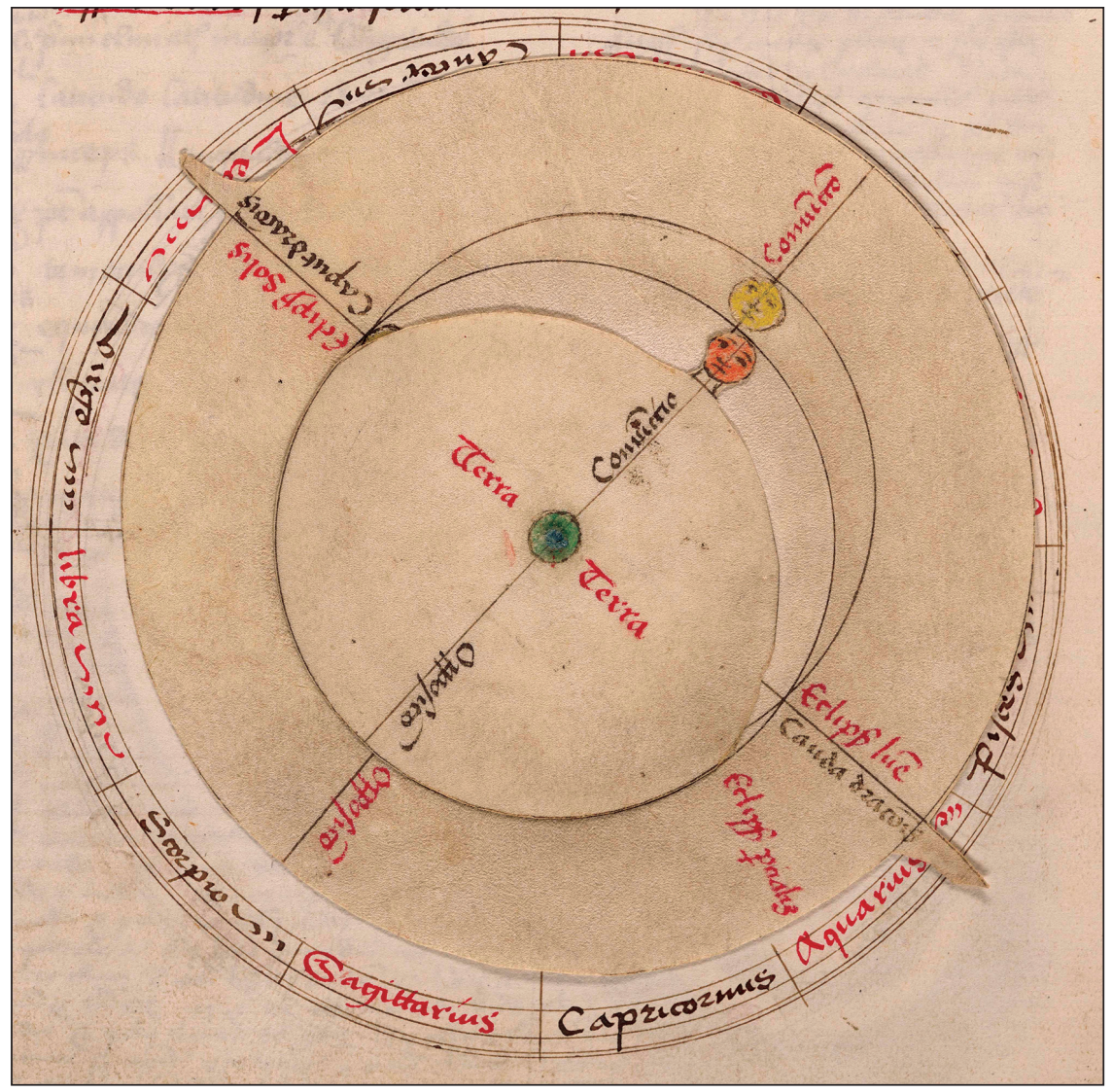

FIGURE 8. Volvelle illustrating the conditions required for eclipses to occur. University of Pennsylvania, Kislak Center for Special Collections, Rare Books and Manuscripts, MS Codex 1881, fol. $35 \mathrm{v}$.

Perhaps the most striking diagram in this codex is an image of the climata, or the seven climatic zones of the earth. MS Codex 1881 contains two climata diagrams, the smaller of which merely provides the names and dimensions of each clime (fol. 33r). In contrast, the larger climata diagram (fol. 33v) is essentially a world map: here, the scribe has copied out dozens of place

when the full moon was at one of these two points; thus Sacrobosco accounted for the fact that eclipses did not occur at every full moon. 
Malcolm: Sacrobosco's De Sphaera Mundi in UPenn MS Codex 1881

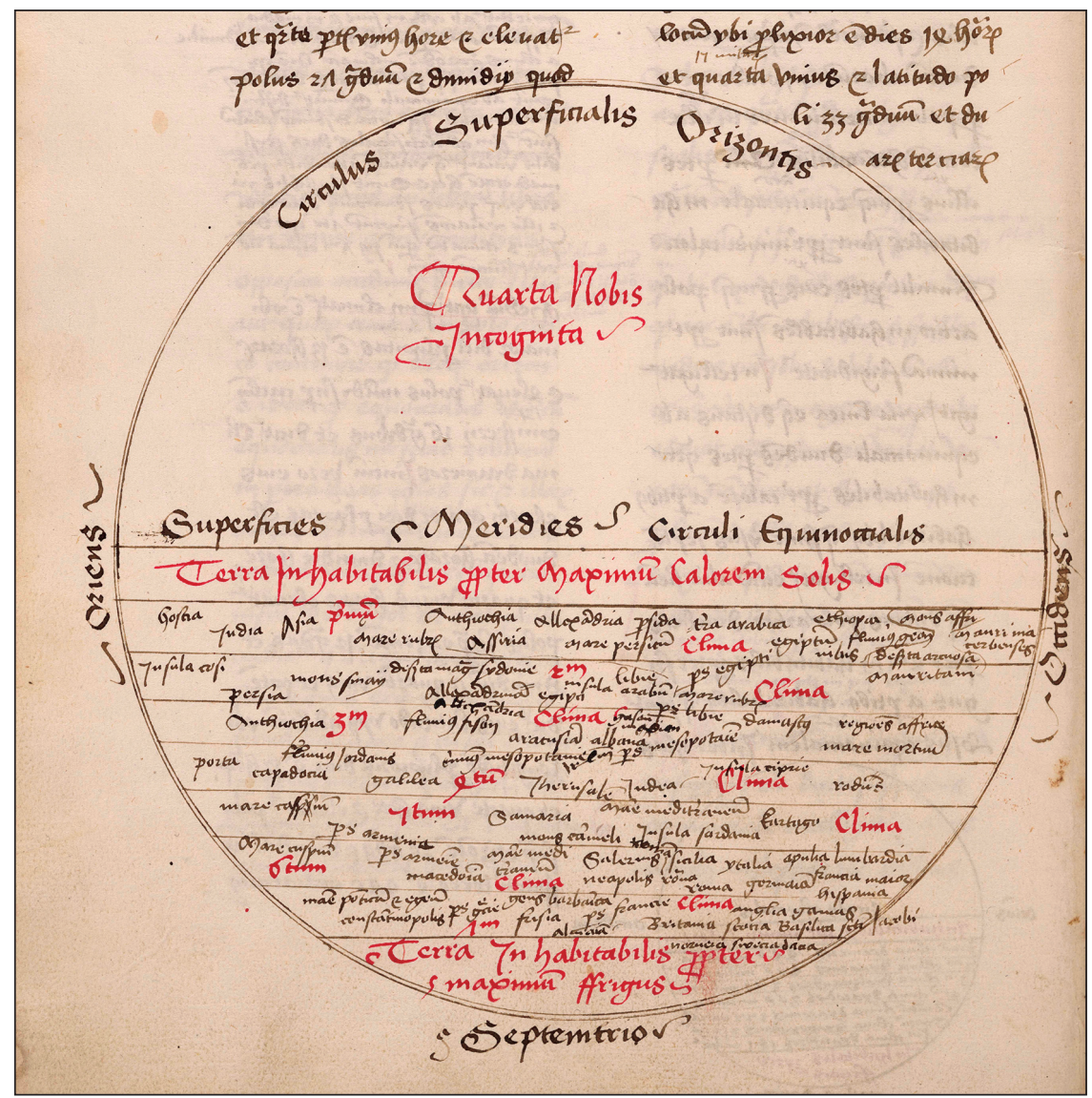

FIGURE 9. Diagram of the seven climata. University of Pennsylvania, Kislak Center for Special Collections, Rare Books and Manuscripts, MS Codex 1881, fol. 33v.

names, including cities, bodies of water, and landmarks (fig. 9). Although some late medieval climata diagrams are purely schematic, it was not uncommon for these diagrams to include the names of the climes and certain representative place names. ${ }^{51}$ However, the encyclopedic character of the 1881 diagram is unusual, as is its tendency to repeat place names across multiple

51 For a schematic climata diagram without text, see University of Pennsylvania, Kislak Center for Special Collections, Rare Books and Manuscripts, LJS 216, fol. 16v. 
climes; this repetition of names could have been inspired by the actual boundaries of regions such as Egypt or Libya, but it is surprising that some cities occur in multiple climes (e.g., Alexandria and Antioch), suggesting that the creator may have been compiling from several sources and registering their disagreements. ${ }^{52}$ Faith Wallis has described how computus tables could be transformed into diagrams through the imposition of a geometric form, producing figures that depict "relationships and patterns that are visually satisfying and evocative." ${ }^{33}$ The large climata diagram in 1881 is a similar hybrid figure, though likely the outcome of an opposite process: by filling this conventional image with text, the scribe has arguably made its visual unity secondary to its data. The result is a compendious diagram that condenses a large amount of geographical knowledge into a compact form.

The substantial range of subjects covered by these skilfully executed diagrams makes 1881 a valuable case study of late medieval astronomical illustration. I am therefore working to produce interactive online editions of some of its images, as well as rotatable digital versions of both its static diagrams and its volvelles. ${ }^{54}$ Figure 10 shows an edition of the larger climata diagram, created using the Omeka application and the Neatline plugin. The user can hover over a place name to view a semi-diplomatic transcription (including all variants of this name in the diagram) or click to view an English translation. This digital resource therefore joins a long tradition of

52 Another detailed climata diagram from the fifteenth century, though lacking the repetition of place names in 1881, is the seventh figure in Pierre d'Ailly's Imago mundi. For a reproduction, see Pierre d'Ailly, Imago mundi, ed. Edmond Buron, 3 vols. (Paris: Librairie orientale et américaine Maisonneuve Frères, 1930), 1:140. Available on Gallica at https:// gallica.bnf.fr/ark:/12148/bpt6k6572456q (accessed 20 December 2019). See also Alfred Hiatt's discussion of its relationship with the lost climata diagram described in Roger Bacon's Opus maius: Terra Incognita: Mapping the Antipodes before 1600 (Chicago: University of Chicago Press, 2008), 145-46.

53 Faith Wallis, "What a Medieval Diagram Shows: A Case Study of Computus," Studies in Iconography 36 (2015): 1-40 at 32. According to Wallis, a diagram is a "primarily geometrical ... representation of an abstraction or concept," while a table "is not structured by geometrical relationships; instead, its structure is determined by the data it contains"; see pages 3-4. 54 For the full series, see Aylin Malcolm, The World of the Sphere: Diagrams from "De sphaera mundi," http://aylinmalcolm.com/sacrobosco. 
Malcolm: Sacrobosco's De Sphaera Mundi in UPenn MS Codex 1881

Malcolm, Orbit of the Sphere | 201

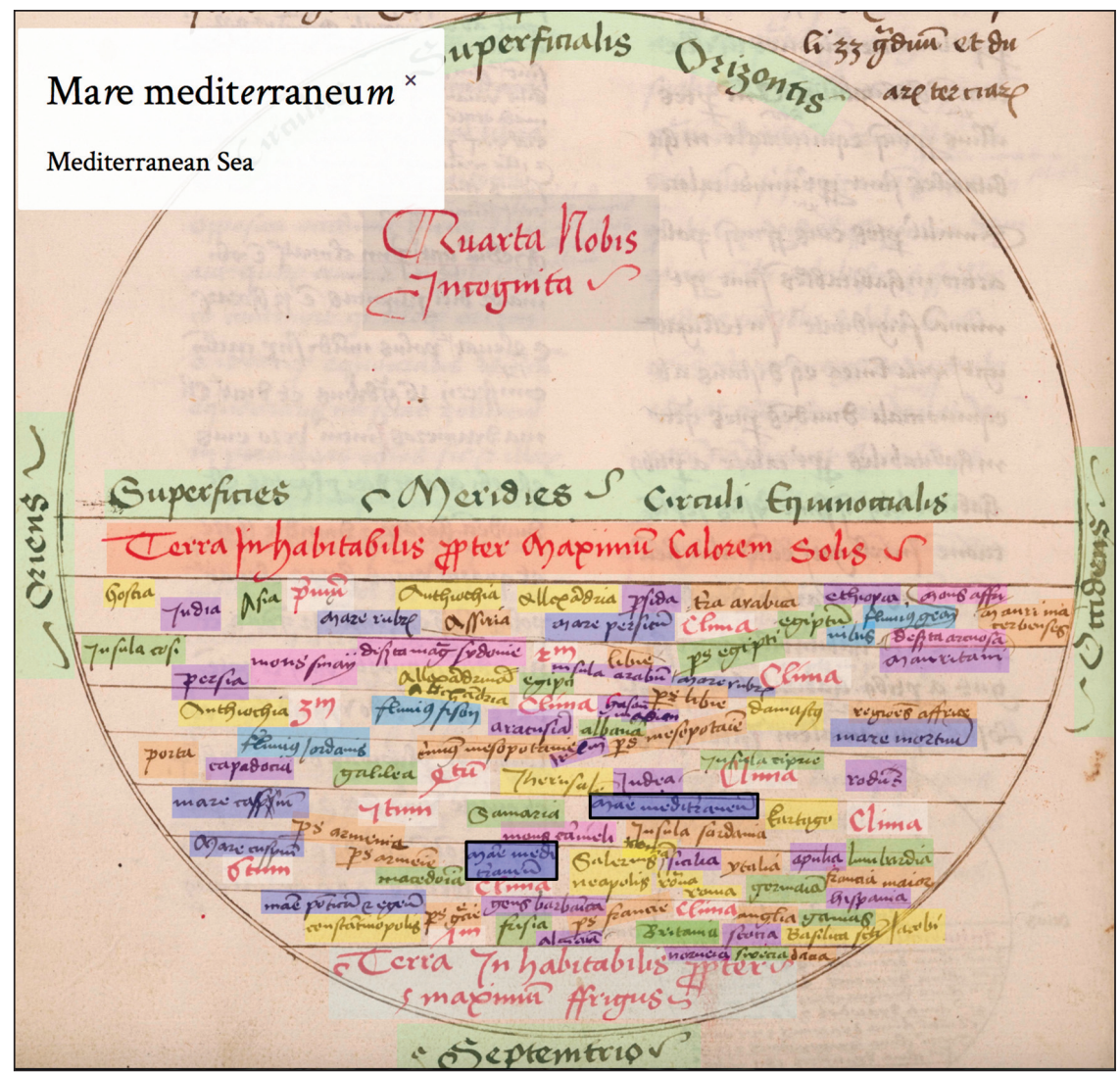

FIGURE 10. Digital edition of the climata diagram from MS Codex 1881, fol. 33v, created using Omeka and Neatline. The user has clicked on one of the two instances of "Mare mediterraneum.” Available at http://aylinmalcolm.com/sacrobosco.

commentary on De sphaera. By inviting users to manipulate these diagrams - not in the mind, nor on the page, but onscreen-I hope to update them for a twenty-first-century audience while preserving a sense of their original purposes.

With its layers of text and commentary and its detailed diagrams, MS Codex 1881 exemplifies the affordances of hand-copied codices and the reasons for which scientific manuscripts continued to circulate well after the advent of print. Although some astronomical incunables were highquality objects, produced using the most advanced printing techniques of 
their period, manuscripts remained a practical alternative until the sixteenth century, since handwritten texts could effectively convey hierarchies within the text and allowed for illustrations with complex annotations and color schemes. ${ }^{55}$ MS Codex 1881 might be considered both an ordinary and an extraordinary example of these later astronomical manuscripts, as a codex containing a typical selection of popular texts accompanied by unusual diagrams and an understudied gloss on De sphaera. It therefore stands to benefit both research and education today. Though it has long been obsolete as a textbook, the emergence of low-cost, accessible digital technologies suggests that this particular codex could gain a larger sphere of influence than ever before.

55 A leading figure in early scientific printing was Erhard Ratdolt, whose numerous innovations included tricolor diagrams in his 1485 edition of De sphaera (ISTC no. ij00406000). 